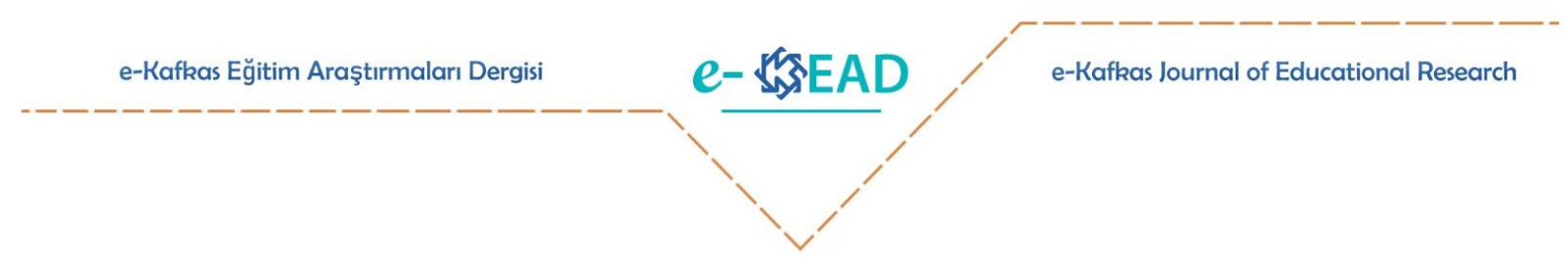

\title{
Turkish Primary-Level EFL Teachers' Views on the Scope and Effectiveness of Content-Based English Instruction ${ }^{1}$
}

\author{
İrem Kışlal $^{2}$ Melike Ünal Gezer ${ }^{3}$
}

\section{To cite this article:}

Kışlal, İ. \& Ünal Gezer, M. (2021). Turkish primary-level EFL teachers' views on the scope and effectiveness of content-based English instruction. e- Kafkas Journal of Educational Research, 8, 612626.doi: 10.30900/kafkasegt.1019971.

\section{Research article}

Received:06.08.2021
Accepted:25.12.2021

\begin{abstract}
The present study aims to report on the perceptions of a group of English as a foreign (EFL) teachers' on content-based instruction (CBI) in English as a foreign language teaching and its effectiveness for primary school students. The teachers participating in the study offered English as a foreign language through CBI and they were interviewed about their perspectives in terms of CBI lessons and the nature of overall program. In-service English language teachers working with young language learners received questions about the effectiveness of CBI, the advantages and disadvantages of implementation of CBI and their experiences and observations with it. The results show that CBI is a major opportunity for language teachers to increase the quality of English instruction with young language learners. Teaching and learning through content is fun and worthwhile both for students and teachers. Data collected through focus group interview reveal that teachers have positive attitudes towards CBI and they are quite informed about the scope and effectiveness of this instructional program for young language learners. Findings of the present study have important implications for policy makers and educational planning in Turkey by creating authentic learning opportunities integrating content matter with foreign language instruction.
\end{abstract}

Keywords: Teaching English to young learners, young language learners, content-based instruction, CBI, English-as-a-foreign language,

\footnotetext{
${ }^{1}$ This research was produced from a part of the first author's master's thesis.

2 (D) Corresponding Author, M.A. Graduate, English Language Teacher, kislalirem@ gmail.com, Ankara, Turkey

3 (iD) Asisst. Prof., melike.gezer@tedu.edu.tr, TED University, Faculty of Education, Department of English Language Education, Ankara, Turkey
} 


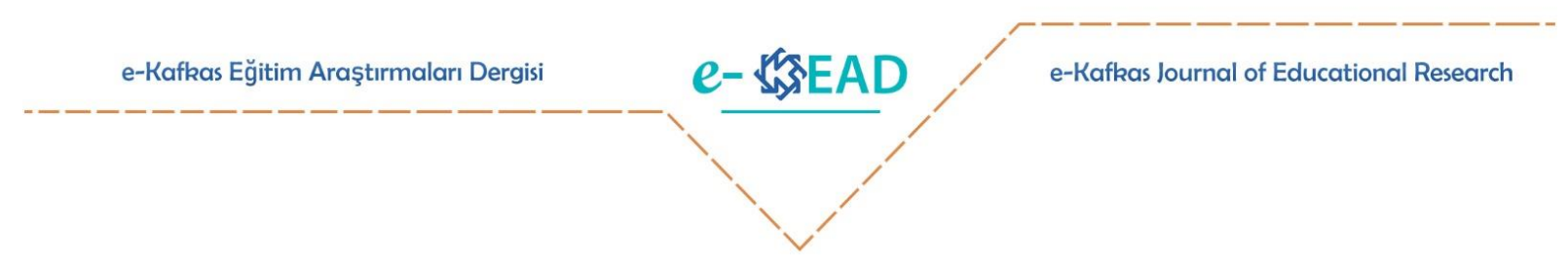

\title{
İçerik Temelli İngilizce Öğretimi Kapsam ve Etkililiği Üzerine İlkokul İngilizce Öğretmen Görüșleri ${ }^{1}$
}

\author{
İrem Kışlal ${ }^{2} \quad$ Melike Ünal Gezer ${ }^{3}$
}

\section{Atıf:}

Kışlal, İ. \& Ünal Gezer, M. (2021). Turkish primary-level EFL teachers' views on the scope and effectiveness of content-based English instruction. e- Kafkas Journal of Educational Research, 8, 612626.doi: 10.30900/kafkasegt.1019971.

\section{$\ddot{O} z$}

Bu çalı̧̧ma ilkokul düzeyinde İngilizce öğreten bir grup İngilizce öğretmeninin içerik temelli yabanc1 dil öğretimi etkililiği üzerine olan algılarını raporlamayı hedeflemiştir. Katılımcı öğretmenler içerik temelli İngilizce öğretim programını temel alan bir kurumda İngilizce eğitimi vermiş ve bu programın genel hatları ve efektif oluşuyla ilgili durumları anlamak adına oluşturulan mülakatlara katılmışlardır. Erken yaş İngilizce öğrenenlerle çalışan hizmet içi İngilizce öğretmenlerine içerik temelli İngilizce öğretiminin etkililiği üzerine sorular verilmiş ve mülakatlarında içerik temelli İngilizce öğretiminin güçlü ve zayıf yönlerini ve kendi tecrübelerini bildiren paylaşımlarda bulunmuşlardır. Mülakatın içerik analizleri, içerik temelli İngilizce öğretiminin genel olarak yabancı dil eğitimine katkılar sunacağını göstermiştir. İçerik esaslı İngilizce öğrenimi ve öğretimi hem öğrenenler hem de öğretenler için hem öğretici hem de eğlenceli öğrenme firsatları sunmaktadır. Hedef grup mülakatları ilgili öğretmen grubunun hem erken yaş öğrenenler için içerik temelli yabancı dil öğretimi ile ilgili gerekli bilgi ve beceri donanımına sahip olduklarını hem de katılımcı öğretmenlerin bu metoda pozitif tutum sergilediklerini bulgulamıştır. Bu çalışmanın bulguları eğitim politikası yapan ve program oluşturan yetkililere yabancı dil öğretiminde otantik ve içerik temelli öğrenme firsatları sunmaları konusunda çıkarımlar sağlamayı hedeflemektedir.

Anahtar Sözcükler: Erken yaş yabancı dil öğrenenler, çocuklara yabancı dil öğretimi, içerik temelli öğretim, hizmet içi İngilizce öğretmeni

\footnotetext{
${ }^{1} \mathrm{Bu}$ araştırma birinci yazarın yüksek lisans tezinin bir kısmında üretilmiştir.

2 (i) Sorumlu Yazar, Bilim Uzmanı, İngilizce Öğretmeni, kislalirem@gmail.com, Ankara, Türkiye

3 (D) Doktor Öğretim Üyesi, melike.gezer@ @tedu.edu.tr, TED Üniversitesi, Eğitim Fakültesi, İngiliz Dili Eğitimi A.B.D., Ankara, Türkiye
} 


\section{Introduction}

Content-based instruction (CBI) in foreign language teaching has been used in various educational contexts such as content-based academic writing courses, ESP (English for Specific Purposes) courses since 1980 and its popularity in Europe increased in the 1990s (Richards \& Rodgers, 2001). This method aims to teach foreign language and content at the same time. Barwell (2005) defines $\mathrm{CBI}$ as teaching and learning the target language through subject areas (mathematics, science, arts, etc.) in the same classroom, at the same time. Richards and Rogers (2001) stated that CBI is a foreign language teaching method shaped around a certain topic or content. In CBI, students focus on the structure of the language around the identified topic. In this way, content and language learning takes place simultaneously and language learners are exposed to the target language with authentic materials. Coyle (2007) indicated that CBI includes the learning of the target language and it is used as a vehicle for content learning for authentic and meaningful language learning classrooms. With this method, students learn a foreign language in relation to the world in their own natural environment. It offers students an opportunity to communicate the target language in an environment which is rich in authenticity and acquisitional processes. In this way, implicit language learning takes place which is unconscious. In teaching English to young language learners, the focal point for language development and in-classroom-dynamics are more fluency rather than accuracy-oriented. In other words, it aims to enable students to use the second language communicatively around meaningful tasks and purposes (Davila \& Vela, 2011). The main purpose is to be able to communicate with each other in a foreign language within the framework of the content.

The first implementation of CBI in Turkish context started at Anatolian High Schools. The system proved to be successful at the acquisition of EFL. According to Bozdoğan and Karlıdağ (2013), CBI has not been comprehensively applied at all education levels in Turkey. CBI is observed mainly in universities at some faculties. It is mentioned in Turkey's Education Vision 2023 that different disciplines, such as mathematics, natural sciences, social sciences, and the visual arts will be integrated with English language education so that students can use the foreign language in various fields.

Content-based teaching facilitates communication for students by providing an authentic language learning environment. According to Tedick, Jorgensen and Geffert (2001), as the language occurs in a meaningful context, language acquisition takes place naturally. Students learn the target foreign language in its natural environment, not in molds. Contents are organized coherently in CBI so students remember and transfer to the long-term memory more feasibly (Davila \& Vela, 2011). It is also another advantage of CBI that students who have negative attitudes towards English course receive opportunities to convert their negative attitudes to the positive (British Council, 2013).

Marsh (2008), viewed CBI as a combination of language and subject learning. In CBI classes, teachers want students to practice the language through content. CBI integrates language learning with the learning of some other content that students are interested so it is not merely a language program (Larsen-Freeman, 2004). Larsen-Freeman (2004) stated that the students' role is to attend the lessons actively and to use content to learn language and use language to learn content. Learning content and language together keeps students interested so students are not left behind in CBI lessons.

\section{Aim and Significance of the Study}

The importance of learning English is always emphasized in Turkey. However, it is widely accepted that the foreign language learning success rate is not enough (Ministry of National Education, 2017). It is already difficult for the students to integrate the target language in their real lives and make use of it actively as global citizens. A solution for this obvious problem is to make learning English a meaningful activity. That is, instead of forcing students to memorize some abstract rules of grammar and put certain vocabulary items in correct places in the blocks of sentences, they may be provided with meaningful and purposeful activities during which they need to use English in order to convey meaning. Bruton (2011) indicated that teaching English with meaningful activities sets the essence of CBI as it integrates content and language instruction. The number of studies related to content-based teaching method in English language instruction with young language learners in EFL contexts is limited as most of the studies come from bilingual and immersion programs in ESL countries (Yalçı, 2007). There is 
a pressing need for further studies conducted in the EFL context to explore the efficacy of CBI in EFL. In different countries, there are studies that have worked with university students and these studies ask learners' opinions towards CBI (Bruton, 2011; Vazquez, 2009; Zarobe \& Lagabaster, 2010). Some other studies have applied to EFL teachers to learn about their experience with this method (Huang, 2011; Pladevall-Ballester \& Vallbona, 2016; Snow \& Brinton, 1997). According to British Council's Survey (2013), there are problems about teaching English as a foreign language and CBI makes communication a meaningful event for students by providing an authentic language learning environment.

The present study aims at exploring the scope and effects of CBI in early English-as-a-foreign language teaching through teacher interviews. In the light of the present study, integration of content and language is recommended for a more successful EFL instruction in Turkey. The study is expected to contribute to the field of foreign language teaching in Turkish context through its scope and the implications of the findings. The present study aims to disseminate the knowledge of the effectiveness of CBI and make this instructional system more accessible in EFL contexts such as Turkey. With this purpose, it is aimed to answer the question "What are Turkish primary school EFL teachers' views on the scope and effectiveness of CBI program specifically for early English language instruction?"

\section{Literature}

Content-based instruction can assist the process of concurrently learning subject matter and new language. CBLT can come in many forms and due to this reason it can be regarded as "an umbrella term for a multifaceted approach to second or foreign language teaching that... shares a common point of departure -- the integration of language teaching aims with content instruction" (Snow, 2014, p. 439).

According to Brinton, Snow, and Wesche (1989) CBLT refers to "the concurrent study of language and subject matter with the form and sequence of language presentation dictated by content material". When the nature of this type of instruction is considered, it contrasts sharply with many other practices in which language skills are taught in isolation from the content. When language becomes the medium to convey content of interest and relevance to the learner, learners then are pointed toward matters of meaningful concern. Language has the role of a vehicle for accomplishing a set of content goals.

$\mathrm{CBI}$ involves the integration of content objectives such as topics covered in subject area courses into a foreign language teaching curriculum. Immersion programs are good examples of CBI. CBI is more of a philosophical orientation rather than a methodological system. Rather it shares many principles with communicative approaches to instruction and task-based learning where the learner actively takes part in the learning journey.

The reconceptualization of CBI is content and language integrated learning (CLIL) that became widespread in Europe in 2000s. Both CBI and CLIL involve meaningful integration of content into language teaching with various levels of exposure to L2. Bayyurt and Yalçın (2014) differentiate between the contexts where language learning takes place to draw a line between CBI and CLIL. While CBI pertains to the ESL contexts where language learning goes on outside of the classroom and for daily purposes, content language integrated learning (CLIL) is what takes place in EFL contexts where language instruction is limited to language classroom with few opportunities to learn outside of instructional contexts. Baker (2011) supports this differentiation by claiming that content-based second language instruction is what is observed in the US, and in Europe this is called CLIL. In language across the curriculum, students' skills, knowledge, understanding, and attitudes are fed with the curriculum areas.

In the center of $\mathrm{CBI}$ are meaning negotiation-construction and focus on meaning rather than form. According to Stoller and Grabe (1997), CBI curriculum helps students develop basic interpersonal communication skills (BICS) and cognitive academic language proficiency (CALP) simultaneously. While CALP skills are academically-oriented, students are expected to develop more complex language abilities through authentic content. In EFL contexts, learners do not have enough opportunities to advance their BICS. In CBI or CLIL classrooms where the acquisition of knowledge and skills are of primary importance, the learners play the key role. CBI programs can be categorized as content-driven where content is the primary focus and language is in the secondary position and language-driven where the language is the primary focus and content instruction is incidental. 
Glancing over the existing literature reporting studies on content-language integrated language instruction in Turkey, Bayyurt and Alptekin (2000) developed a thematic curriculum for young learners attending to a private school to tap into conceptual and linguistic knowledge in both native and target language. Young learners exposed to a theme-based syllabus design resulted in developing stronger language proficiency in listening/ and reading/writing than the control group (2007).

In the late $20^{\text {th }}$ century a wide-spread adoption of content-based curricula around the world increased the potential of increasing intrinsic motivation by shifting the attention of learners to a concurrent working of subject matter and linguistic ability. The advent of CBLT brought along challenges such as new curricula and materials and training for instructors. CBLT brings new dimensions to teaching with team-teaching models where subject area experts and language teachers work collaboratively. Task and theme based curriculum are part of CBLT.

Whether the school follows a program where English is treated as a separate subject or English is integrated as naturally as possible into the existing primary program is a question Pinter (2006) ponders upon. Some countries adopt a subject-based teaching in the primary school and thus English as a separate subject might fit better. In these contexts, English is offered in limited amounts for about two hours a week and often a specialist teacher teaches the language. Other countries have already opted for an integrated approach where English is carefully embedded into the primary curriculum. In these contexts, English is taught by the class teacher. This suggests that children have the chance to link their knowledge in mathematics, science, music, or geography with English. Some sort of integration between the rest of the curriculum and the foreign language sounds logical for numerous reasons. Because younger children learn holistically, integrating English into other learning would be logical. Recycling various concepts and words in a foreign language can reinforce previously taught information.

In many contexts, English is used across the curriculum in a systematic way throughout the primary years. In such contexts, Content and Language Integrated Learning (CLIL) is often used. This is very similar to integrating language and content in multilingual classrooms in that both content and language are developed simultaneously. In Finland, children start English at the age of nine and have a gradual increase of English throughout their primary school. English language learning can be integrated to other aspects of the curriculum such as geography, arts, and mathematics, and by the end of primary school, children may end up using English as often as their mother tongue.

It is often assumed that integrated teaching or content-based teaching is associated with large amounts of ongoing contact hours because it is not possible to engage students with lacking proficiency in meaningful, content relevant activities. However, an interesting study in the USA found that this was not the case. Huang, a China-based researcher, conducted a study in 2003 with children aged 9-11 enrolled in a Chinese as a FL program in the USA. These children were learning Chinese for two hours per week and did not have Chinese speaking relatives to practice with outside school. Despite these limitations, the teachers decided to implement a content-driven program. This meant that the cultural content was first planned and language emerged from meaningful cultural topics such as comparing the daily routines of Chinese and American children of similar ages. In this study, children found contentdriven teaching motivating and fulfilling and with the use of good visuals and other supporting materials, the learners, despite limited proficiency, were able to communicate with each other and learn new content through the target language. This research may inspire other teachers working with lower level classes of children to explore the opportunities of content-based teaching.

Content-based instruction is "an approach to second language teaching in which teaching is organized around the content or information that students will acquire, rather than around a linguistic or other type of syllabus" (Richards \& Rodgers, 2001, p. 204). CBI integrates language learning through content instruction. The target language is practiced through a subject matter. This is thought to be a natural way of developing target language skills and it corresponds to the way the first language is originally learnt. Students acquire the target language unconsciously. Content-based teaching differs from traditional language classes because language comes second to the content. Meyer (2010) stated that learners create their own language and understanding and develop their skills.

The basic premise of CBI in language learning is that learning takes place effectively when language learners are exposed to meaningful input and when they are required to complete purposeful 
tasks. The curricula in CBI settings are organized around content rather than mere forms and structures. CBI fosters students' communicative competence in foreign language (Stryker \& Leaver, 1997). Students are exposed to a considerable amount of language while learning content. Communicative classrooms are characterized by activities and tasks that have a purpose and require meaningful exchange of information (Met, 1998).

Ideal conditions that Krashen proposes for second language learning hold another implication for CBI classroom. Krashen (1985) suggested that methods that provide language learners with comprehensible input can be more effective than mere memorization of language forms and vocabulary items provides learners with opportunities to use language as a means for meaningful interaction like real-life situations. CBI provides learners with opportunities to use language as a means for meaningful interaction like real-life situations. Students have real-life experiences in language classrooms as purposeful activities are organized. It affects students' success positively (Bruton, 2013). CBI suggests second language instruction to be similar to the first language acquisition. CBI tries to provide learners with conditions that are similar to real-life conditions so that language learners can learn a second language through contextual cues, meaningful, and purposeful activities. CBI enables students to reach knowledge in situations that are close to real life situations and it can be a way to build a connection between what is learned in school and what is experienced in real-life settings.

Content-centered, content-related, content-enriched, content-based instruction (CBI) also referred to as content and language integrated learning (CLIL) for young language learners is a way to contextualize language instruction by integrating it with other learning, especially what is being taught and learned in other classes. It provides opportunities to reinforce the academic skills and knowledge learned in other classes and draws on topics and activities to bring the experiences of learning another language to those academic content areas (Crandall, 1994, 1998; Curtain \& Dahlberg, 2010). It connects English curriculum with other parts of the students' academic lives. It can also make English for young learners (EYL) much more interesting and engaging. If we are teaching about wild animals, learning about where they live (geography) and what they eat (science) will connect English to what they have been learning in other classes. We can grow beans in a pot when reading Jack and the Beanstalk in our EYL classes (science). Students can even plan a simple budget for a class party and calculate the money needed to buy cake and juice (math). There is so much content that can be used as the basis for motivating children to learn English and to support their academic achievement as well.

While integrating academic content with English is important for all learners, it becomes increasingly important as children get older, they need to study a subject through the medium of English. In a real world, people learn language and content simultaneously, as can young learners in EYL classes. We can incorporate local and national culture for content in the EYL class. Local traditions, stories, folktales, games, customs and rituals, and holidays are included and children's experiences in their own language are linked to the new language: English.

To understand content-based instruction, we need to have a better grasp of contextualizing language instruction. We also need to understand how they pick up on their first language. Children learn their first language in an environment in which they have authentic or real reasons to use the language; they are surrounded by its use and they are highly motivated to use it. In language classes, there is less reason to use the language or to be motivated to do so. We need to provide reasons for children to use English to motivate them and engage them and to connect the classroom with home, neighborhood and community, Genesee (2000) points out that 'instruction for young language learners, in particular, should take into account their need for context-rich, meaningful environments. There are ways to contextualize language instruction: bright and lively posters or pictures related to the theme of the lesson, displays of children's drawings, stories, or other work, realia (objects related to the theme or story), a storytelling corner where children can sit on the floor close to the teacher while she reads a story.

\section{Content-Based Instruction in EFL Classes}

The main contribution of CBI to foreign language learning is to acquire the language skills and content at the same time for the students and the content-based teaching will create a language learning environment which increases the importance of content in language teaching by putting an end to the 
artificial dissection of form and function in foreign language classes (Yalçın, 2013). In this way, it will be possible to motivate students and increase the productivity of the English learning process. It is concluded that CBI in foreign language teaching is an effective method and it may become possible to make this method a preferable one especially for environments, like Turkey, where English is offered as a foreign language. Although the positive effects of CBI are obvious in EFL context for primary school students, there is limited number of studies in this context.

Content- based teaching has not been proposed recently. In 1970s, teaching language was integrated into other subject areas (Larsen-Freeman, 2004). To ensure quality of English language education, a continuous discussion of the needs of the English language learners and different teaching models have been presented (Krashen, 2003; Short, 1993; Snow, Met \& Genesee, 1989). Harmer (2007) indicated that these models, however, are usually not used in public school settings, but in adult ESL environments or college ESL classes at English language institutes. The rising trend is for primary schools to build interdisciplinary curricula around contents to promote more learning (Loepp, 1999). Lasagabaster and Sierra (2009) stated that as a result of working hard to develop students' foreign language skills, education departments in Europe revealed that CBI is the best way to improve students' foreign language skills. It is suggested as an alternative to bottom-up approaches, ending the unnatural distinction of language and content, which is the result of grammar-based monitoring (Wesche \& Skehan, 2002). CBI focuses on integrating content and language learning in dynamic and relevant learning environments built on 'bottom-up' initiatives as well as 'top-down' policy (Coyle, 2007). It provides students a large view of the subject. Instead of word forms or sentence structures, students focus on meanings. According to Meyer (2010), classroom content focuses on global problems while connecting the daily lives of students and their interest so it is meaningful.

CBI in EFL context has already proved its merits as shown by several studies. Zhang and Ke (2017) conducted a research concentrating on the relationship between CBI and English learning ability. They indicated that CBI has a positive impact on primary school students' autonomous learning ability. The research tries to explore the students' English autonomous learning ability through CBI with a questionnaire. The students were divided into two groups: CBI and traditional grammar-translation group. As a result, the application of CBI has a positive impact on students' English learning ability thanks to changes in students' autonomous learning psychology, self-paced learning ability and thus autonomy.

Goris (2019) collected longitudinal results from research analysing the impact of CBI on pupil EFL acquisition. The study was conducted in Italy, the Netherlands and Germany. In each of these countries, four groups took part: two groups with CBI and two groups in mainstream classes. Mainstream classes can be described as grammar schools. According to pre and post-test results, it was concluded that CBI provided better EFL learning opportunities for primary school students. Students improved their vocabulary, reading comprehension and idiomatic skills.

Content-based instruction is based on a learner-centred learning environment in which the teachers' role is mentoring. In such a learning environment, students are expected to connect their prior knowledge and experiences with what is presented as new subject matter. Learning becomes meaningful when the learners apply their already existing schemata and skills into new learning situations (Genesee, 1994). CBI lessons activate already existing background knowledge. Learners add up new schema through subject-matter and learning becomes meaningful. As a result, it decreases the anxiety and increases students' motivation and self-confidence. CBI enables learner to grasp the new information with the help of the previous learning. Met (1998) emphasizes that authentic experiences in meaningful contexts promote learning. In a CBI classroom, learners are able to connect pieces of information with what they have learnt in other lessons.

\section{CBI and Curriculum Development}

Rather than forms, functions and situations, subject should be in the center in a CBI curriculum. In CBI, students are asked to look for the overall meaning before attending to the sentence level such as vocabulary and syntax. Students must learn to think what content means in order to know what they are looking for in language. In this way, they learn language through content. 
An authentic language and text is used in CBI while teaching language. The core materials in CBI are used with the subject matter of the content course. Coyle (2007) recommends that authentic materials are identified and utilized. As students focus on the subject matter, they acquire linguistic ability. Students practice the target language through various subjects. This is a natural way of developing language skills and it corresponds to the way the first language is acquired (Stryker \& Leaver, 1997). Learning activities should focus on understanding and conveying meaningful messages and they should include realistic tasks using authentic materials (Bruton, 2011). Nonetheless, finding teaching materials such as texts that are lower than students' level can affect students negatively. Meyer (2010) stated that if the teacher simplifies the text according to students' proficiency level, students can benefit from authentic materials in any content area. Teachers should select the content carefully not to face any problems about language and the topic in target language teaching process. Students develop a mechanism to deal with the target language in other contexts and it fosters the development of foreign language skills (Stryker\& Leaver, 1997). Generally teachers believe that some grammatical rules and vocabulary must be learned first. However, this kind of a view does not allow students to learning language by using it. It cannot be a model of how people communicate in EFL context. There are some suggested teaching strategies for teachers: using context effectively, recycling information, exploiting students' background knowledge and schemata, using pair work or group work (Met, 1991; Stryker\& Leaver, 1997).

The content and learning activities should be appropriate to students' needs and interests. CBI curriculum must meet students' needs and it needs to be flexible (Coyle, 2007). When teachers monitor students carefully, they could be aware of students' needs. Coyle (2007) indicated that teachers can make necessary adjustments in the curriculum in this way. As Krashen (1982) stated with 'low affective filter', the teacher should always be aware of students' needs. When students feel demotivated, they might lose their interest towards the target language. Teachers should care about their students' thoughts while designing the curriculum. There is a strong relation between content and language growth (Stryker \& Leaver, 1997). When the content material is abstract and challenging for students, it could be difficult to teach content. Stryker and Leaver (1997) stated that choosing content relevant to students' experience could be helpful for students to acquire the target language. Students could comprehend the target language with visuals and their concrete experience with the help of suitable contents (Harmer, 2007).

\section{Method}

The present research aims to examine EFL teachers' views on the scope and effectiveness of CBI program specifically targeting at early English instruction. This research is based on qualitative design. Having conducted open-ended interviews with the teachers involved in the study, the research analyzed the data qualitatively with codes emerging into themes. The current study involved semistructured interviews in order to get an in-depth understanding of the views of teachers on the scope and effectiveness of a CBI program. To give the participants the opportunity to express their thoughts and feelings in detail, semi-structured interview was the preferred data collection method. The researcher interviewed three teachers that are the EFL teachers of each class.

\section{Setting and Participants}

The setting is a private institution following content-based instruction method for primary-level English instruction. All the third and fourth grade classes had a main English teacher and there were three teachers that were interviewed for this study. The teachers were asked to learn about their English CBI program practice and young language learners' skills development. They are non-native, EFL teachers with varying levels of experiences in teaching. EFL teaching experience ranged between three to seven years.

\section{Data Collection and Data Analysis}

Data collection process took about an academic semester which was approximately three months. In this timeframe, teachers were interviewed about their perspectives in the effectiveness the CBI lessons and content-based instruction in general. The interviews were carried out mainly in English even though the interviewees were given the option of conducting the interview in Turkish as well. The teachers were asked questions based on the "Teacher Interview Schedule". There were questions about students' general performances in CBI lessons, their point of view towards CBI and the difficulties that 
the students encounter. The teachers involved in the study were also interviewed about their perspectives in terms of CBI lessons and program. The interviews were carried out in English and the entire interview was audio-recorded. There were three teachers and each teacher lectured one class at grades 3 and 4; each were given a pseudonym as T1, T2 and T3. Teachers were asked open-ended questions (see Appendix I).

Teacher interview data rich with in-service English teacher reflection were analysed via content analysis procedures. In order to analyse the qualitative data collected from interviews, the researchers first listened to the recordings multiple times. This was necessary to gain familiarity with the content and second to generate codes (Creswell, 2007; Denzin \& Lincoln, 2003). For transcription purposes. The transcriptions were coded to determine meaning units based on research questions and literature.

In order to ensure reliability of the coding of in-service English teacher interviews on CBI, two coders worked with the data and an inter-coder agreement was reported to overcome potential reliability and validity concerns. The analyses of the content and the coding procedures necessitated several turns until the emerging themes were secured. The most commonly emerging codes and the themes were listed in the findings section. The coding and the rest of the analyses were done by two raters and the scoring agreement (Fraenkel, Wallen, \& Hyun, 2012) reached 80\%, indicating that the agreement was reasonably high.

\section{Findings}

This chapter reveals the findings of the research which is aimed at exploring the effects of CBI in foreign language teaching through teacher interview. Emerging themes after the coding of the teachers' responses are presented as following:

Table 1.

Summary of the Data from the Teacher Interviews

\begin{tabular}{ll}
\hline Common statement & $f$ \\
\hline Defining CBI & 3 \\
authentic/ natural method & 2 \\
connecting target language and content & 2 \\
Differences of CBI & 3 \\
providing permanent learning & 3 \\
teaching implicitly & \\
CBI as a good model & 3 \\
fostering curiosity & 3 \\
attracting students' interest & \\
Serving the needs of our country & \\
easy to arrange according to students' needs & 2 \\
convenient to include the advances in technology & 3 \\
Being effective & \\
autonomous students & 3 \\
positive attitudes towards target language & 3 \\
Teachers' thoughts towards CBI & \\
satisfaction & 3 \\
being a modern teacher & 2 \\
improving teaching skills & 2 \\
Reasons to continue teaching with CBI & \\
increasing curiosity & 2 \\
student collaboration & 3 \\
enjoyment & 2 \\
Difficulties that teachers encounter & \\
finding contents according to all students' interests & \\
content knowledge of teachers themselves & 2 \\
\hline$f=$ frequency & 2 \\
& 2 \\
\hline
\end{tabular}




\section{Teachers' Background Knowledge about CBI}

Firstly, teachers were asked to explain CBI with their own words and explain what makes it different than the other teaching programs. CBI was defined commonly as a bridge that needs to be created while teaching the target language and the content together for the second language learners. T1 stated that "I believe that teaching the significant information and language together is possible only when we use CBI in our education system." In addition, teachers indicated that CBI is a natural and authentic teaching method that resembles the way of acquiring native language. T3 explained "We learn vocabulary and grammatical structures in daily matters in a gradual and natural process with CBI. So it can be concluded that CBI is a relatively natural method that we use to teach a new language."

They stated that CBI focuses on integrating the learning of a language with learning of contents or academic subjects in the classroom rather than learning the language itself as one of the differences of CBI. T2 indicated that "As the structure and vocabulary of the target language are given indirectly with in a content that is age appropriate, it's less intimidating for the learners, - especially the young ones - and also more interesting." Similarly, T1 explained the difference of CBI as "Since CBI is not interested in teaching just grammar, vocabulary etc., it has a billion of content to teach the language in harmony with the topics. This is the main difference that provides permanent learning". While comparing CBI with other teaching programs, they indicated the positive effect of teaching target language by integrating it with content. Based on the overall primary English teachers' statements, it can be concluded that they all agreed it would be important to adopt CBI in our education system.

\section{Perspective in Effectiveness}

Teachers also touched upon their own feelings during the instructional applications. They all agreed that CBI was a beneficial model for students and it fosters students' interest and curiosity. T1 stated: "CBI gives us a great chance to teach language as well. For example, most of the teachers find simple past tense easy to teach. They show the grammar, time adverbials. After all, they assume that students learn all aspects of simple past tense. However, we teach simple past tense with an interesting topic like 'history of inventions'. Students become curious to learn the past of planes, cars, phones etc. When we get their attention, we can teach simple past tense really easily. This example shows that CBI is beneficial for our children." T3 went: "With interesting contents, students are really curious to learn new things. They do not learn the language in a traditional way which was mostly used in the language classes; they have the ability use the language in their lessons to participate. Additionally, according to teachers, none of the students are missing in the class and generally all the students are attending the lessons. Meaning, there is something for all the students." T3 indicated that not all the students are equally competent in all the subjects so with CBI you get the chance to include each student in the learning process through these different subjects. Moreover, T2 stated: "The most effective aspect of it is its being convenient to include the advances in technology, the most recent topics and developments, daily matters, etc. in your lesson plans. The world is changing rapidly and so do the topics that people are interested in. So if you keep your content up-to-date with your students' interests, you can provide a more thriving learning environment."

It can be concluded that teachers feel beneficial and effective when they teach the contents and language together. As they study different topics and subjects to offer, they feel productive. The students become more autonomous and independent. They have fun while teaching the target language with content and so do their students.

Additionally, it was reported that students enjoy CBI lessons mostly. They attend the lessons eagerly. CBI motivates them towards learning a second language. They indicated that CBI helps students participate in the class because learners are expected to be more active in different roles and cooperate with each other. Teachers emphasized those positive attitudes towards CBI increasing the overall quality of learning.

\section{Appropriateness to Turkey and Turkish Students' Needs}

According to the teachers, CBI can easily be arranged according to our children's needs. CBI is not a program that you cannot change or modify. T2 indicated that "In a world that changes and develops every day, we can combine the language and the content effectively thanks to using CBI". CBI enables 
teachers to teach the language and the content in a context-embedded manner. Another aspect of CBI is its convenience to include the advances in technology, the most recent topics and developments and daily matters in your lesson plans. T1 explained it as "The world is changing rapidly and so do the topics that people are interested in. So if you keep your content up-to-date with your students' interests, you can provide a more thriving learning environment" especially considering the limited amount of English exposure of young English learners in Turkey. As a conclusion, CBI helps students participate in the class as active leaners, adopting different roles, cooperating with each other and enhancing the quality of language learning for young learners in Turkey.

\section{Challenges in CBI Lessons}

Although teaching and learning through the content is fun and worthwhile for students and teachers, teachers touched upon certain difficulties. While designing the curriculum and selecting the themes, students' interests should be taken into consideration. T1 pointed out the importance of curriculum design as "If the students are not attracted by the topic or they are already intimidated by the subject such as mathematics, it can be challenging to include them in the lesson." Similarly, T2 stated that "There are some topics that are not so attractive for certain young language learners. For example fashion units are not most favourable content/theme for boys. It was not easy to take their attention during the whole unit. It was the only difficulty of CBI program for me: finding a common ground for all of my young learners."

It is stated by the teachers that CBI is useful for students and teachers. CBI offers students to have a successful learning atmosphere. Although it takes time to plan and create materials and there are some challenges, the results should be taken into consideration because learner readiness, teacher knowledge and the balance between the language and the content are key points of CBI model.

\section{Conclusion and Discussion}

The results supported the existing literature that language and content integration provides the opportunity for meaningful communication in purposeful social and academic contexts. Language learning occurs when learners are exposed to target language while learning a subject matter through the language. Research on CBI programs is quite limited in the EFL context (Yalçın, 2007). The present study, having studied with a unique group who were English language instructors of young language learners at a primary English education program in Turkey, aimed to further extend the existing literature by exploring the effect of language and content integration on early language learning through teacher interview.

The research question was about the Turkish EFL teachers' views on the scope and effectiveness of CBI program. For this purpose, the teachers answered open-ended questions about students' language development. The questions were about students' general performances in CBI lessons and teacher perspectives on the program. The content-analysis of the interviews with teachers revealed some patterns and effectiveness was one of the most significant terms emerging as a theme. Participating teachers indicated that CBI affected students' performance and their views towards foreign language learning positively and it enabled students to improve their target language skills. Teachers further explicated that CBI lessons affected students' views towards other subjects, too. Those study findings are aligned with the literature supporting content-based instruction (Brown, 2011; Cameron, 2001; Shin \& Crandall, 2014). After teaching EFL with CBI, teachers indicated that they had great satisfaction of being a modern and effective teacher thanks to CBI program. Additionally, they note that they feel like they improve their knowledge and skills with CBI. Teacher interviews confirm that with CBI, lessons are more fun and productive and that in-service English language teachers' professional development on content-based language instruction should be an integral component (Celce-Murcia, Brinton, \& Snow, 2014).

Having investigated the nature of an English program following CBI at primary levels, the present study reports evidence in positive impact of the program on the learners and the teachers. Integration of language and content yields beneficial results for every stake-holder. The results of the present study have the curricular and pedagogical implications that language and content integration provide a meaningful and purposeful learning context for students. When language is a medium for meaningful communication through authentic interactions, activities have a real purpose and require an 
authentic exchange of meaning. The subject matter learning enables learners to improve their reading and writing skills as they are able to develop schemata about a subject through the course and the learners are able to apply already existing schema into new learning situations.

The widespread idea in early language learning and teaching is that children best acquire when they are immersed in a context where natural exposure to the target language takes place with the use of authentic language learning tools. The study had limitations such as a small sample size. Yet the interview data provided us with an in-depth in-service teacher reflection and insight for the scope and effectiveness of a CBI program for young English language learners. As for the directions for future studies, conducting studies with larger sample sizes, including multiple institutions, and working with teachers who are familiar with CBI and those who are not, are several recommended paths.

\section{Copyrights}

The works published in e-Kafkas Journal of Educational Research are licensed under a Creative Commons Attribution-NonCommercial 4.0 International License.

\section{Etik Beyannamesi}

Bu çalışmada "Yükseköğretim Kurumları Bilimsel Araştırma ve Yayın Etiği Yönergesi” kapsamında belirtilen kurallara uyulduğunu ve "Bilimsel Araştırma ve Yayın Etiğine Aykırı Eylemler" başlığı altında belirtilen eylemlerden hiçbirini gerçekleştirmediğimizi beyan ederiz. Aynı zamanda yazarlar arasında çıkar çatışmasının olmadığını, tüm yazarların çalışmaya katkı sağladığını ve her türlü etik ihlalinde sorumluluğun makale yazarlarına ait olduğunu bildiririz.

\section{Etik Kurul İzin Bilgileri}

Etik kurul adı: Başkent Üniversitesi Sosyal ve Beşeri Bilimler ve Sanat Araştırma Kurulu

Etik kurul karar tarihi: 17.11.2017

Etik kurul belgesi sayı numarası: 17162298.600-129 


\section{References}

Baker, C. (2011). Foundations of bilingual education and bilingualism. Multilingual Matters.

Barwell, R. (2005). Critical issues for language and content in mainstream classrooms: introduction. Linguistics and Education, 16, 143-150.

Bayyurt, Y., \& Alptekin, C. (2000). EFL syllabus design for Turkish young learners in bilingual education contexts. In J. Moon \& M. Nikolov (Eds.), Research into teaching English to young learners, (pp. 312-322). Pecs: Pecs University Press.

Bayyurt, Y., \& Yalçın, S. (2014). Content based instruction. In S. Çelik (Ed.), Approaches and principles in English as a foreign language (EFL) education, (pp. 200-223). Eğiten Kitap.

Bozdoğan, D. \& Karlıdağ, B. (2013). A case of CLIL practice in the Turkish context: lending an ear to students. Asian EFL Journal Research Articles, 15, 89-110.

Brown, D. (2011). Teaching by principles: An interactive approach to language pedagogy. White Plains, NY: Pearson.

Bruton, A. (2013). CLIL: Some of the reasons why and why not. System, 41, 587-597.

Bruton, A. (2011). Is CLIL so beneficial, or just selective? Re-evaluating some of the research. System, 39, 523-532.

Brinton, D. M., Snow, M. A., \& Wesche, M. J. (1989). Content-based second language instruction. New York: Newbury House.

British Council. (2013). Türkiye'de İngilizce Öğretimi Araştırması. Retrieved from https://www.britishcouncil.org.tr/programmes/education/research

Cameron, L. (2001). Teaching languages to young learners. Cambridge: Cambridge University Press.

Celce-Murcia, M., Brinton, D., \& Snow, M. A. (2014). Teaching English as a second or foreign language.

Boston: National Geographic Learning.

Coyle, D. (2007). Content and language integrated learning: towards a connected research agenda for CLIL pedagogies. International Journal of Bilingual Education and Bilingualism, 10, 543-562.

Crandall, J.A. (1998). Collaborate and cooperate: teacher education for integrating language and content instruction. English Teaching Forum, 36, 2-9.

Crandall, J. A. (1994). Content-centered language learning. ERIC Clearinghouse on Languages and Linguistics, Center for Applied Linguistics, Washington DC.

Creswell, J. W. (2007). Qualitative inquiry and research design. Choosing among five approaches $\left(2^{\text {nd }}\right.$ ed. $)$. Sage.

Curtain, H., \& Dahlberg, C. A. (2010). Languages and children: making the match (4 ${ }^{\text {th }}$ ed.). Pearson.

Davila, H. A. H. \& Vela, M. L. C. (2011). A case study on content based instruction for primary school children. How Journal: A Colombian Journal for Teachers of English, 18, 112-134.

Denzin, N. K., \& Lincoln, Y.S. (2003). Collecting and interpreting qualitative materials. Sage.

Fraenkel, J. R., Wallen, N. E., \& Hyun, H. H. (2012). How to design and evaluate research in education. McGraw-Hill.

Genesee, F. (2000). Brain research: implications for second language learning. ERIC Clearinghouse on Languages and Linguistics, Center for Applied Linguistics, Washington DC.

Genesee, F. (1994). Language and content: Lessons from immersion (Educational Practice Report No.11). Washington DC: Center for Applied Linguistics, and National Center for Research on Cultural Diversity and Second Language Learning.

Goris, J. (2019). Content and Language Integrated Learning in English as a Foreign Language: A European Perspective. Radbout University.

Harmer, J. (2007). The practice of English language teaching (4 ${ }^{\text {th }}$ ed.). Pearson.

Huang, K. (2011). Motivating lessons: A classroom-oriented investigation of the effects of content-based instruction on EFL young learners' motivated behaviors and classroom verbal interaction. System, 39, 186-200.

Krashen, S. (2003). Explorations in language acquisition and use: the Taipei lectures. Heinemann.

Krashen, S. D. (1985). The Input hypothesis: Issues and implications. Cambridge University Press.

Krashen, S. D. (1982). Principles and practise in second language acquisition. Pergamon.

Larsen-Freeman, D. (2004). Techniques and Principles in Language Teaching. Oxford University Press. 
Lasagabaster, D. \& Sierra J. M. (2009). Immersion and CLIL in English: more differences than similarities. ELT Journal, 64, 367-375.

Loepp, F. L. (1999). Models of curriculum integration. The Journal of Technology Studies, 25, 21-25.

Marsh, D. (2008). Language awareness and CLIL. In N. H. Hornberger (Ed.), Encyclopedia of language and education. Springer.

Met, M. (1998). Curriculum decision-making in content-based language teaching. In J. Cenoz \& F. Genesee (Eds.), Beyond bilingualism: Multilingualism and multilingual education, (pp. 35-63). Multilingual Matters.

Met, M. (1991). Learning Language through Content: Learning Content through Language. Foreign Language Annals, 24, 281-295.

Meyer, O. (2010). Introducing the CLIL-pyramid: Key strategies and Principles for Quality CLIL planning and teaching. In, M. Einsenmann, \& T. Summer (Eds.), Basic issues in EFL-teaching and learning. Heidelberg.

Milli Eğitim Bakanlığı (2017). English language curriculum for primary education. Ankara: Talim ve Terbiye Kurulu Başkanlığı

Pinter, A. (2006). Teaching young language learners. Oxford University Press.

Pladevall-Ballester, E. \& Vallbona, A. (2016). CLIL in minimal input contexts: A longitudinal study of primary school learner's receptive skills. System, 58, 37-48.

Richards, J. C., \& Rodgers, T. S. (2001). Approach and method in language teaching. Cambridge University Press.

Shin, J. K., \& Crandall, C. A. (2014). Teaching young learners English: from theory to practice. Cengage Learning.

Short, D.J. (1993). Assessing integrated language and content instruction. TESOL Quarterly, 27, 627656.

Snow, M. A. (2014). Content-based and immersion models of second/foreign language teaching. In M. Celce-Murcia, D. M. Brinton, \& M. A. Snow (Eds.),Teaching English as a second or foreign language, (pp. 438-354). Heinle Cengage Learning.

Snow, M. A. \& Brinton, D. M. (1997). The content-based classroom: perspectives on integrating language and content. Longman.

Snow, M. A., Met, M. \& Geneese F. (1989). A conceptual framework for the integration of language and content in second/foreign language instruction. TESOL Quarterly, 23, 201-217.

Stoller, F. L., \& Grabe, W. (1997). A six-Ts approach to content-based instruction. In M.A. Snow \& D.M. Brinton (Eds.), The content-based classroom: perspectives on integrating language and content, (pp.53-66). Longman.

Stryker, B. S. \& Leaver L. B. (1997). Content-based instruction in foreign language education: models and methods. Washington D.C.: Georgetown University.

Tedick, D., Torgensen, K. \& Geffert, T. (2001). Content-based language instruction: the foundation of language immersion education. The Bridge: From Research to Practice, 4, 1-8.

Turkey Education Vision 2023. (2019). T.C. Ministry of Education. Retrieved from http://2023vizyonu.meb.gov.tr

Vazquez, R. (2009). Motivating student through content-based instruction. Published master's thesis. Pirhua University.

Wesche, M. B., \& Skehan, P. (2002). Communicative, task-based, and content-based language instruction. In R. B. Kaplan (Ed.), The Oxford handbook of applied linguistics, (pp. 207-228). Oxford University Press.

Yalçın, Ş. (2013). İçerik temelli yabancı dil öğretim modeli. Boğaziçi Üniversitesi Eğitim Dergisi, 30, $107-121$.

Yalçın, Ş. (2007). Exploring the effects of content-based instruction on skill development, domainspecific knowledge and metacognition in the L2. Published master's thesis. Boğaziçi University.

Zarobe, Y. R. \& Lasagabaster, D. (2010). CLIL in Spain: implementation, results and teacher training. Cambridge Scholar Publishing.

Zhang, J. \& Ke Q. (2017). The impact of CBI on college English autonomous learning ability. 4th International Conference on Advanced Education and Management, 264-270. 


\section{Appendix- Teacher Interview Schedule}

1. What is CBI in your own words? How would you define it? What is in the nature of it?

2. What does CBI do differently than other instructional programs?

3. Do you think CBI is a good model for your students? Why? Can you give some examples?

a) Do you think CBI serves the need of our country? Our country's children?

b) Do you think CBI is an effective one? If so, which aspect of it is effective?

4. Did using CBI activities during the lessons have any effect on your thoughts and attitudes?

Can you give some examples?

5. Do you want to continue teaching English with CBI during the following academic terms? Can you explain the reasons why or why not?

6. What were the conveniences and difficulties that you encounter during CBI lessons?

7. Is there anything that you want to add or explain about CBI lessons 